Acta vet. scand. 1981, 22, 162-170.

From the State Veterinary Institute for Virus Research, Lindholm, Denmark.

\title{
FETAL INFECTION \\ WITH PORCINE PARVOVIRUS IN HERDS WITH REPRODUCTIVE FAILURE
}

By

K. J. Sфrensen and J. Askaa

SØRENSEN, K. and J. ASKAA: Fetal infection with porcine parvovirus in herds with reproductive failure. Acta vet. scand. 1981, 22, 162-170. - During a 20 months period in 1978 and 1979 aborted, macerated and mummified fetuses as well as stillborn piglets from herds with reproductive failure were examined for evidence of infection with porcine parvovirus (PPV). A total of 602 cases were examined and evidence of infection with PPV was found in $269(45 \%)$. In $52 \%$ of these antibody to PPV was found. Infective PPV as well as antibody to PPV were found in $41 \%$, whereas infective PPV alone was found in $7 \%$. When abortions were excluded from the results a high prevalence of infection with PPV (73-90\%) was found among fetuses of all sizes with the exception of fetuses dead late in gestation or at term.

porcine parvovirus; pig fetuses; reproductive f a il u re.

Several reports concerning occurrence of porcine parvovirus (PPV) in dead fetuses have appeared (Cartwright \& Huch 1967, Johnson 1969, 1973, Morimoto et al. 1972, Rondhuis \& Straver 1972, Mengeling et al. 1975, Donaldson-Wood et al. 1977, Forman et al. 1977, Horner \& Hunter 1977, Mengeling 1978). Embryonic and fetal deaths have been induced experimentally by infecting susceptible gilts and sows (Mengeling \& Cutlip 1976, Joo et al. 1976 a, 1977, Mengeling et al. 1980), indicating that PPV is a common cause of reproductive failure in pigs. Furthermore, abattoir studies have demonstrated a high prevalence of the infection in fetuses from small litters (Cropper et al. 1976) and in fetuses from litters with macerated and mummified fetuses and remnants of embryos (Mengeling 1978). 
In the present work the prevalence of infection with PPV in dead fetuses from Danish pig breeding herds with reproductive disorders was estimated.

\section{Specimens}

\section{MATERIALS AND METHODS}

During a period of 20 months in 1978 and 1979 all aborted, macerated and mummified pig fetuses as well as stillborn piglets received for diagnostic laboratory investigation* from herds with cases of fetal death were examined for evidence of infection with PPV.

Samples of lung and liver tissues (usually about $8 \mathrm{~g}$ ) were collected and pooled under sterile conditions for virus isolation.

Fetal fluids from the thoracic cavity or, in case of complete dehydration, extracts in PBS of brain tissue were collected for antibody examination. Fetuses of similar size from the same herd had their samples pooled. Thus a case may yield one or more samples depending on the sizes of the fetuses submitted.

\section{Cell cultures}

Primary cultures of pig kidney cells (PPK) from 2-3-weekold pigs were grown in $11 \times 4 \mathrm{~cm}$ glass bottles (Schott bottles). Growth medium consisted of modified Hank's balanced salt solution containing $0.75 \mathrm{~g} \mathrm{NaHCO}_{3} / \mathrm{l}$ and supplemented with $5 \%$ fetal calf serum, $0.5 \%$ lactalbumin hydrolysate, a vitamin solution as used in Eagle's MEM, (Glasgow modification), neomycin $(0.05 \mathrm{mg} / \mathrm{ml})$ and dihydrostreptomycin $(0.1 \mathrm{mg} / \mathrm{ml})$. Maintenance medium was Earle's salt solution supplemented as mentioned above.

\section{Serum}

Anti PPV hyperimmune serum was produced in rabbits by 3 subcutaneous inoculations of about $1 \mu \mathrm{g}$ of sucrose gradient purified PPV (strain 893) (Lei et al. 1980) emulsified in Freundt's incomplete adjuvant. The inoculations were performed at weekly intervals. Serum was stored at $-20^{\circ} \mathrm{C}$ until use.

* At the State Veterinary Serum Laboratory, Copenhagen or at the State Veterinary Institute for Virus Research, Lindholm. 
Detection of virus

Homogenates $(10 \%)$ were prepared by grinding the tissues in a Colworth Stomacher 80 (A. J. Seward, Burry st., Edmunds, Suffolk) for about 2 min with serumfree maintenance medium with additional antibiotics, i.e., penicillin (1000 i.u./ml), dihydrostreptomycin $(1 \mathrm{mg} / \mathrm{ml})$ and polymyxin B (1000 i.u./ml). The homogenates were clarified by low speed centrifugation for 20 min. From each sample $8 \mathrm{ml}$ were transferred to a Schott bottle containing a 40-50\% confluent monolayer of PPK cells, which had been washed twice in serumfree maintenance medium before use. After adsorption for $1 \mathrm{~h}$ at $37^{\circ} \mathrm{C}$ the cell cultures were drained and washed twice before addition of maintenance medium. After 5 days of incubation at $37^{\circ} \mathrm{C}$ the cells were subcultured. Volumes of $2 \mathrm{ml}$ containing about $5 \times 10^{4}$ cells $/ \mathrm{ml}$ in maintenance medium were added to $1 \times 3 \mathrm{~cm}$ tubes with coverslips (Leighton tubes) and incubated at $37^{\circ} \mathrm{C}$. Control cultures, which were mock-infected with maintenance medium with additional content of antibiotics as described, were maintained in parallel. After 5 days of incubation, cultures from 2 Leighton tubes were examined for evidence of PPV replication by immunofluorescence microscopy (Sфrensen et al. 1980). Rabbit anti PPV hyperimmune serum (produced as mentioned above) and FITC conjugated anti rabbit IgG serum (DAKO-immunoglobulins Ltd., Copenhagen) served as immuno reagents for identification of PPV.

\section{Detection of antibody}

Fetal fluids were tested for specific antibody using the indirect immunofluorescent antibody test (IFAT) and the counterimmunoelectrophoresis test (CIET) (Sфrensen et al.).

\section{RESULTS}

A total of 602 cases were examined for evidence of infection with PPV (Table 1). In 139 cases antibody to PPV in fetal fluids was the only evidence of infection. PPV as well as antibody to PPV were found in $\mathbf{1 1 0}$ cases, whereas PPV alone was found in 20 cases. In total, evidence of infection with PPV was found in $269(45 \%)$ of the cases examined.

Abortions comprised 132 cases, and of those infection with PPV was found in 10 (Table 2). 
T a b le 1. Demonstration of PPV antibody and infective PPV from 602 cases of fetal death in commercial pig breeding farms.

\begin{tabular}{lcc}
\hline & Number of cases & $\%$ \\
\hline PPV antibody alone & 139 & $52^{1}$ \\
PPV antibody and PPV & 110 & 41 \\
PPV alone & 20 & 7 \\
\hline Total PPV positive & 269 & $45^{2}$ \\
\hline 1 out of 269 pasitive. & & \\
2 out of 602 cases. & & \\
\end{tabular}

The 602 cases examined comprised 642 samples, where the crown-rump measures were recorded. Table 2 summarizes the prevalence of infection with PPV in the fetuses grouped according to crown-rump measures. Excluding abortions from the data, the prevalence of infection with PPV was very high $(73-90 \%)$ among fetuses of all sizes with the exception of fetuses dead late in gestation or at term. Antibody to PPV was readily detected in fetuses of all sizes down to crown-rump measures of about $12 \mathrm{~cm}$. PPV was isolated most frequently from fetuses with crown-rump measures of less than $12 \mathrm{~cm}$ and least frequently from fetuses dead near or at term. Clear cytopathic effects of viral replications were occasionally observed, but generally infection of the cell cultures was recognized by immunofluorescence microscopy.

T a b le 2. Prevalence of infection with PPV according to crownrump measures of 642 samples of fetuses and groups of fetuses of similar size.

\begin{tabular}{llllll}
\hline $\begin{array}{l}\text { Crown-rump } \\
\text { measures }(\mathrm{cm})\end{array}$ & \multicolumn{2}{c}{ All } & Abortions & \multicolumn{2}{c}{ Non-abortions } \\
\hline$<10$ & \multicolumn{1}{c}{$8 / 45^{1}$} & $(18 \%)$ & $0 / 34^{1}$ & $8 / 11^{1}$ & $(73 \%)$ \\
$10-13$ & $47 / 74$ & $(64 \%)$ & $0 / 22$ & $47 / 52$ & $(90 \%)$ \\
$14-17$ & $60 / 86$ & $(70 \%)$ & $3 / 13$ & $57 / 73$ & $(78 \%)$ \\
$18-21$ & $59 / 111$ & $(53 \%)$ & $4 / 41$ & $55 / 70$ & $(79 \%)$ \\
$22-25$ & $36 / 85$ & $(42 \%)$ & $3 / 22$ & $33 / 63$ & $(52 \%)$ \\
$26-29$ & $10 / 29$ & $(34 \%)$ & - & $10 / 29$ & $(34 \%)$ \\
Stillborn & $82 / 212$ & $(39 \%)$ & - & $82 / 212$ & $(39 \%)$ \\
\hline
\end{tabular}

1 PPV positive/total number examined. 


\section{DISCUSSION}

Losses from reproductive disorders are of great concern in Danish pig breeding herds. Nielsen \& Bendixen (1969) found that $8.7 \%$ of piglets born by gilts were stillborn or mummified. Bille et al. (1974) reported, that $5.9 \%$ of piglets were stillborn or mummified, and in a recent investigation (Anon. 1979) mummification was found in $3.8 \%$ of the litters examined.

In the present work evidence of infection with PPV was found in $45 \%$ of the cases examined showing that the infection is commonly found in connection with fetal death in Danish pig breeding herds.

Infection with PPV can also cause embryonic death (Mengeling 1979, Mengeling et al. 1980, Wrathall \& Mengeling 1979) resulting in return to estrus or "pseudopregnancy" with persistent corpora lutea without the presence of live embryos (Rodeffer et al. 1975), or birth of small litters (Cropper et al. 1976). Such cases are not recorded in the present work, since they usually leave no dead fetuses for laboratory investigation.

The material examined comprised 132 cases which were recorded as abortions. PPV was isolated from 10 of these. Also Cartwright \& Huck (1967) isolated PPV from aborted fetuses. These findings, however, may be coincidences, since abortion due to fetal death in pig is uncommon. In fact, a prolongation of the gestation period tends to take place if all fetuses eventually die (Wrathall 1975). This is supported by DonaldsonWood et al. (1977), who found that abortion was not a sequel to PPV infection in a susceptible pig herd, and by Gillich (1977), who found no evidence of increase in the number of abortions during an outbreak of PPV induced reproductive failure. Neither have abortions been a sequel to experimental infections with PPV (Mengeling \& Cutlip 1975, 1976, Cutlip \& Mengeling 1975, Joo et al. 1976a). When abortions were excluded from the present investigation a very high prevalence of infection with PPV was found among fetuses of all sizes with the exception of those dead late in gestation or at term. Mengeling (1978) found a similar prevalence of infection with PPV in dead fetuses from slaughtered sows. The results are also in agreement with data from experimental infections with PPV resulting in mummification, stillbirth or birth of apparently normal piglets, with the highest mortality when the infection occurred before the last 
part of the mid third of gestation (Mengeling \& Cutlip 1975, 1976, Cutlip \& Mengeling 1975, Joo et al. 1976a).

The porcine fetus has been found able to produce antibody after stimulation with antigen at about 2 months of gestation (Binns 1967, Fennestad et al. 1968, Bourne et al. 1974). However, after infection of fetuses with subsequent death and mummification it can be difficult to relate exact gestational age to crown-rump measures possibly due to shrinkage of young collagen in intervertebral discs (Joo et al. 1976a) and probably also due to growth retardation in a variable period of time from infection to death. Infected fetuses in the present study with crown-rump measures of about $12 \mathrm{~cm}$ may therefore have been alive until a gestational age of about 60 days or more and been able to mount an antibody response. Joo \& Johnson (1977) applied antibody assays for routine diagnosis too, but by using hemagglutination inhibition (HI) tests for demonstration of antibody in fetuses with crown-rump measures $>18 \mathrm{~cm}$. They avoided fetuses with crown-rump measures $16 \pm 1 \mathrm{~cm}$ in routine diagnosis as these fetuses often had neither HI-antibody nor hemagglutinating (HA)-antigen, whereas smaller fetuses often had high titers of HA-antigen but no HI-antibody. Joo et al. $(1976 \mathrm{~b})$ also found that fetuses with HI-antibody did not show HA-antigen, although infective virus could be isolated in cell cultures. This was probably due to inhibition of HA-antigen by HI-antibody, and similarly it can be assumed, that excess of HA-antigen in smaller fetuses with crown-rump measures down to about $12 \mathrm{~cm}$ prevented the detection of $\mathrm{HI}$-antibody, since antibody in such fetuses could be demonstrated by the methods used in the present study.

\section{ACKNOWLEDGEMENT}

The authors thank Mrs. Irene Houmann Poulsen and Mrs. Marianne Berglund for excellent technical assistance.

\section{REFERENCES}

Anon.: Svineavl og -produktion i Danmark 1979. (Swine breeding and production in Denmark 1979). Landsudvalget for svineavl og -produktion, Andelsslagteriernes fælleskontor, Axelborg, Copenhagen 1979, p. 36.

Bille, N., N. C. Nielsen, J. L. Larsen \& J. Svendsen: Preweaning mortality in pigs. Nord. Vet.-Med. 1974, 26, 294-313. 
Binns, R. M.: Bone marrow and lymphoid cell injection of the pig foetus resulting in transplantation tolerance or immunity, and immunoglobulin production. Nature (Lond.) 1967, 214, 179181.

Bourne, F. J., J. Curtis, R. H. Johnson \& D. F. Collings: Antibody formation in porcine fetuses. Res. Vet. Sci. 1974, 16, 223-227.

Cartwright, S. F. \& R. A. Huck: Viruses isolated in association with herd infertility, abortions and stillbirths in pigs. Vet. Rec. 1967, $81,196-197$.

Cropper, M., H. W. Dunne, A. D. Leman, A. L. Starkey \& D. C. Hoefling: Prevalence of antibodies to porcine enteroviruses and porcine parvovirus in body fluids of fetal pigs from small vs large litters. J. Amer. vet. med. Ass. 1976, 168, 233-235.

Cutlip, R. C. \& W. L. Mengeling: Pathogenesis of in utero infection: Experimental infection of eight- and ten-week-old porcine fetuses with porcine parvovirus. Amer. J. vet. Res. 1975, 36, $1751-1754$.

Donaldson-Wood, C. R., H. S. Joo \& R. H. Johnson: The effect on reproductive performance of porcine parvovirus infection in a susceptible pig herd. Vet. Rec. 1977, 100, 237-239.

Fennestad, K. L., C. Borg-Petersen \& E. Brummerstedt: Leptospira antibody formation by porcine foetuses. Res. Vet. Sci. 1968, 9, $378-380$.

Forman, A. J., C. Lenghaus, G. G. Hogg \& C. J. Hale: Association of a parvovirus with an outbreak of foetal death and mummification in pigs. Aust. vet. J. 1977, 53, 326--329.

Gillick, J. C.: An outbreak of swine foetal mummification associated with porcine parvovirus. Aust. vet. J. 1977, 53, 105-106.

Horner, G. W. \& R. Hunter: Isolation of porcine parvovirus from aborted piglets. N. Z. vet. J. 1977, 25, 25-26.

Johnson, R. H.: A search for parvoviridae (Picodnaviridae). Vet. Rec. $1969,84,19-20$.

Johnson, R. H.: Isolation of swine parvovirus in Queensland. Aust. vet. J. 1973, 49, 157-159.

Joo, H. S., C. R. Donaldson-Wood \& R. H. Johnson: Observations on the pathogenesis of porcine parvovirus infection. Arch. Virol. 1976a, 51, 123-129.

Joo, H. S., C. R. Donaldson-Wood \& R. H. Johnson: Rapid diagnostic techniques for detection of porcine parvovirus infection in mummified foetuses. Aust. vet. J. $1976 \mathrm{~b}, 52,51-52$.

Joo, H. S., C. R. Donaldson-Wood, R. H. Johnson \& R. S. F. Cambell: Pathogenesis of porcine parvovirus infection: Pathology and immunofluorescence in the foetus. J. comp. Path. 1977, 87, $383-391$.

Joo, H. S. \& R. H. Johnson: Observations on rapid diagnosis of porcine parvovirus in mummified foetuses. Aust. vet. J. 1977, 53, 106-107. 
Lei, J. C., E. Overby, M. Holm Jensen \& F. O. Sørensen: Preparation of a porcine parvovirus vaccine. Proc. Int. Pig Vet. Soc. Congr., Copenhagen 1980, p. 64 .

Mengeling, $W$. L.: Prevalence of porcine parvovirus-induced reproductive failure: An abattoir study. J. Amer. vet. med. Ass. 1978, 172, 1291-1294.

Mengeling, W. L.: Prenatal infection following maternal exposure to porcine parvovirus on either the seventh or fourteenth day of gestation. Canad. J. comp. Med. 1979, 43, 106-109.

Mengeling, W. L. \& R. C. Cutlip: Pathogenesis of in utero infection: Experimental infection of five-week-old porcine fetuses with porcine parvovirus. Amer. J. vet. Res. 1975, 36, 1173-1177.

Mengeling, W. L. \& R. C. Cutlip: Reproductive disease experimentally induced by exposing pregnant gilts to porcine parvovirus. Amer. J. vet. Res. 1976, 37, 1393-1400.

Mengeling, W. L., R. C. Cutlip, R. A. Wilson, J. B. Parks \& R. F. Marshall: Fetal mummification associated with porcine parvovirus infection. J. Amer. vet. med. Ass. 1975, 166, 993-995.

Mengeling, W. L., P. S. Paul \& T. T. Brown: Transplacental infection and embryonic death following maternal exposure to porcine parvovirus near the time of conception. Arch. virol. 1980, 65, $55-62$.

Morimoto, T., Y. Fujisaki, Y. Ito \& Y. Tanaka: Biological and physicochemical properties of porcine parvovirus recovered from stillborn piglets. Nat. Inst. Anim. Hith Quart. 1972, 12, 137-144.

Nielsen, H. E. \& H. J. Bendixen: Unders $\varnothing$ gelser over fosterd $\varnothing \mathrm{d}$ hos svin. (Foetal death in swine). Landøk. Fors $\emptyset$ gslab. Årbog. Copenhagen 1969 , p. $23-32$.

Rodeffer, H. E., A. D. Leman, H. W. Dunne, M. Cropper \& D. J. Sprecker: Reproductive failure in swine associated with maternal seroconversion for porcine parvovirus. J. Amer. vet. med. Ass. 1975, 166, 991-992.

Rondhuis, P. R. \& P. J. Straver: Enige kenmerken van een klein, hemagglutinerend DNA-virus, geisoleerd uit een verworpen varkensfoetus. (Some properties of a small haemagglutinating DNAvirus, isolated from an aborted fetus of a pig). Tijdschr. Diergeneeskd. 1972, 97, 1257-1267.

Sфrensen, K. J., J. Askaa \& K. Dalsgaard: Assay for antibody in pig fetuses infected with porcine parvovirus. Acta vet. scand. 1980, 21, 312-317.

Wrathall, A. E.: Reproductive Disorders in Pigs. Review series No. 11 of the Commonwealth Bureau of Animal Health, Commonwealth Agricultural Bureuax, 1975.

Wrathall, A. E. \& W. L. Mengeling: Effect of transferring parvovirusinfected fertilized pig eggs into seronegative gilts. $\mathrm{Br}$. vet. J. $1979,135,255-261$. 


\section{SAMMENDRAG}

Infektion med porcint parvovirus $i$ fostre fra besætninger med reproduktionsproblemer.

Over en 20 måneders periode i 1978 og 1979 blev aborterede, macererede og mumificerede fostre samt døde fuldbårne grise fra besætninger med reproduktionsproblemer unders $\emptyset \mathrm{gt}$ for infektion med porcint parvovirus (PPV). Ialt blev 602 tilfælde unders $\varnothing \mathrm{gt}$, og infektion med PPV blev påvist i $269(45 \%)$. I $52 \%$ af disse fandtes antistof mod PPV. Infektivt PPV samt antistof mod PPV fandtes i $41 \%$, medens infektivt PPV alene fandtes i $7 \%$. Når aborterne blev udelukket fra unders $\varnothing$ gelsesresultaterne, fandtes infektion med PPV i en stor procentdel $(73-90 \%)$ af fostre $i$ alle størrelser med undtagelse af fostre døde sent $\mathrm{i}$ drægtighedsperioden eller ved fødslen.

(Received December 19, 1980).

Reprints may be requested from: K. J. Sørensen, the State Veterinary Institut for Virus Research, Lindholm, DK-4771 Kalvehave, Denmark. 